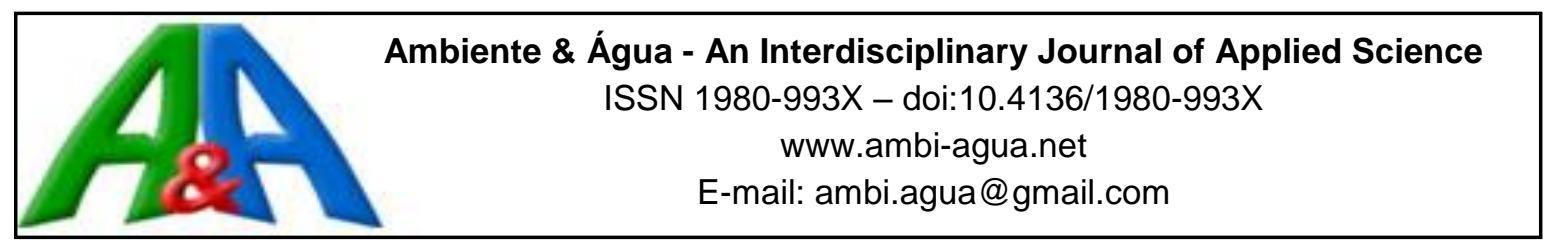

\title{
Research on ecosystem services in Brazil: a systematic review
}

\author{
ARTICLES doi:10.4136/ambi-agua.2263
}

Received: 29 Mar. 2018; Accepted: 24 Mar. 2019

\author{
Lucilia Maria Parron $^{1 *}$; Elaine Cristina Cardoso Fidalgo ${ }^{2}$; \\ Alessandra Polli Luz ${ }^{3}$; Monica Matoso Campanha ${ }^{4}$; Ana Paula Dias Turetta ${ }^{2}$; \\ Bernadete Conceição Carvalho Gomes Pedreira ${ }^{2}{ }^{\circledR}$; Rachel Bardy Prado ${ }^{2}$ \\ ${ }^{\mathbf{1} E m b r a p a ~ F l o r e s t a s, ~ C o l o m b o, ~ P R, ~ B r a s i l ~}$ \\ E-mail: lucilia.parron@embrapa.br \\ ${ }^{2}$ Embrapa Solos, Rio de Janeiro, RJ, Brasil \\ E-mail: elaine.fidalgo@embrapa.br, ana.turetta@embrapa.br, \\ bernadete.pedreira@embrapa.br, rachel.prado@embrapa.br \\ ${ }^{3}$ Universidade Federal do Paraná (UFPR), Curitiba, PR, Brasil \\ Departamento de Engenharia Ambiental (DEA). \\ E-mail: alessandrapolliluz@gmail.com \\ ${ }^{4}$ Embrapa Milho e Sorgo, Sete Lagoas, MG, Brasil \\ E-mail: monica.matoso@embrapa.br \\ *Corresponding author
}

\begin{abstract}
Studies using the 'ecosystem services' (ES) approach developed in Brazil based on the framework of the Millennium Ecosystem Assessment (MEA), and range from quantitative and qualitative evaluation to the development of economic instruments for payment for ecosystem services (PES) or compensation for their maintenance, mainly for hydrological services. In order to summarize current knowledge regarding ES, the structure for teaching in ES, and also to provide a basis for future research in Brazil, we carried out a systematic review of publications on ES and a study on the availability of undergraduate and graduate courses related to ES. We found 282 publications for the 2006-2017 period, which included peer-reviewed articles, books, book chapters, theses, dissertations, articles in annals and technical publications. We identified current knowledge, knowledge gaps and trends in ES researches that may guide surveys and scenario analyses for future studies, in different biomes and regions of the country. Atlantic Forest and Amazon are the most-studied biome. Most of the studies were related to the evaluation of different types of ES and to the development of methodologies for their evaluation and monitoring. The most common ES are related to biodiversity, carbon sequestration and water.
\end{abstract}

Keywords: ecosystem services assessment, hydrological payment for ecosystem services, network analysis.

\section{Pesquisa sobre serviços ecossistêmicos no Brasil: uma revisão sistemática}

\section{RESUMO}

Estudos com a abordagem de serviços ecossistêmicos (ES) desenvolvidos no Brasil com base no quadro da Avaliação de Ecossistemas do Milênio (MEA) variam desde a avaliação 
quantitativa e qualitativa até o desenvolvimento de instrumentos econômicos para pagamento por serviços ecossistêmicos (PES) ou compensação por sua manutenção, principalmente de serviços hidrológicos. Para sintetizar a atual produção de conhecimento e a estrutura de ensino em ES e também fornecer uma base para futuras pesquisas no Brasil, nós realizamos uma revisão sistemática de publicações sobre ES e uma pesquisa sobre a disponibilidade de cursos de graduação e pós-graduação relacionados aos ES. Nossa revisão sistemática encontrou 282 publicações para o período 2006-2017, que incluiu artigos revisados por pares, livros, capítulos de livros, teses, dissertações, artigos em anais e publicações técnicas. Identificamos o conhecimento atual, as interações entre instituições, lacunas de conhecimento e prioridades que deveriam ser consideradas em pesquisas futuras. O artigo fornece informações sobre estudos futuros e é um passo importante para considerar ES como uma abordagem para atingir os objetivos do desenvolvimento sustentável.

Palavras-chave: análises em rede, avaliação de serviços ecossistêmicos, pagamento por serviços ecossistêmicos hídricos.

\section{INTRODUCTION}

Ecosystem services (ES) can be defined as the benefits people obtain from ecosystems (MEA, 2005). The Millennium Ecosystem Assessment framework for ES identified that 15 of the 24 ES are declining at the global level, and can have a major negative impact on human well-being in the future.

Various classification systems for ES have been devised, such as those by De Groot et al. (2002), the Millennium Ecosystem Assessment (MEA, 2005) and The Economics of Ecosystem and Biodiversity (Kumar, 2010). The most common classification system divides ES into four categories: provisioning services, regulating services, habitat/supporting services and cultural services.

Since the Millennium Ecosystem Assessment, many research groups and papers have focused on ES (Martínez-Harms and Balvanera, 2012; Costanza et al., 2016). An example is the IPBES (Intergovernmental Platform on Biodiversity and Ecosystem Services), a platform which assesses the state of biodiversity and the ES it provides to society, in response to requests from decision makers (http://ipbes.net/about-ipbes.html). Another example is the Ecosystem Service Partnership (ESP), which is a worldwide network of scientists, policy makers and practitioners who organize conferences and services to enhance the application of ES for nature conservation, ecosystem restoration and sustainable management (https://www.espartnership.org/). In Brazil, the 'Rede de Serviços Ambientais' (Ecosystem Services Network) is a research group acting in all biomes focused on research, development and public policy on ES (Prado et al., 2015).

The integration produced by different research groups promote advancement of knowledge and stimulate new questions leading to a new cycle of investigations to answer them. The systematic review provides a broad overview of the literature, and from that point, are identified priorities and perspectives for the research. Besides, syntheses are increasingly demanded by scientific journals and funding agencies. Previous analyses of scientific research on ES focused on the global scale (Seppelt et al., 2012), Latin America (Martínez-Harms and Balvanera, 2012), Africa (Egoh et al., 2012), China (Jiang, 2017) and Australia (Plant and Ryan, 2013). However, there are no analyses of Brazilian literature on ES, although the Brazil is one of the most important producers of food, fiber and biofuel in the world and has great biodiversity and vital ecosystems services (Martinelli and Filoso, 2009). In order to combine and summarize Brazilian scientific studies of ES, the structure for teaching in ES and to provide a basis for future research in Brazil, we conducted a systematic review of publications on ES and the

Rev. Ambient. Água vol. 14 n. 3, e2263 - Taubaté 2019 
availability of undergraduate and graduate courses related to ES. From the results obtained, we 1) characterized the published studies; 2) identified current knowledge and existing gaps; 3 ) identified the offer of disciplines in undergraduate and graduate courses in public universities; and 4) suggested priorities for future research.

\section{METHODS}

\subsection{Systematic review of scientific production}

This systematic review was based on published studies of Brazilian ES. To be included in the review, the publications should meet the criteria: a) to be in one of the electronic databases Capes, Scielo or Sabiia; b) to have the keywords 'ecosystem services' and 'environmental services' (in English and Portuguese) in their titles; c) have been published between the period 2006-2017; d) to be published in peer-reviewed journals, books, book chapters, theses, dissertations, articles in proceedings and technical publications. The Sabiia is a Brazilian database that gathers information about agriculture and related areas in peer-reviewed journals, book chapters, thesis and proceedings. The chosen period reveals the progress in previous experiences and reflects the most recent studies on the subject. From the initial research (533 publications), those that did not meet the criterion of the research described above and duplicated in more than one database were excluded. The remaining publications $(n=282)$ were analyzed by their abstracts and text and categorized within the ES to which they referred. We classified the results according to the following metadata: publication year; publication form (e.g. journal, book chapter); research focus (assessment, monitoring, mapping, modeling, methodological development, analysis and opinion, review and economic valuation); classification (provision, regulation, support/habitat and cultural); ES type; biome;approach to payment for ecosystem services (PES) programs; development of technologies and affiliation of authors. More than one ES type, classification and biome per publication was allowed. We used frequency and percentage of publications to show trends and relationships between the data. According to the method, publications which address ES in Brazil but do not have the key words in their titles were not included in the results of our compilation.

The publications were also considered to establish a network analysis between institutions. For this approach, the analysis considered the institution of the publication's authorship obtained by the systematic review. The aim was to identify the predominant players: institutions with the highest numbers of publications on the theme and their interactions. An undirected graph of the network (network analytic software Gephi 0.9.2) was developed considering the institution of the first author and its interaction with others and vice versa. The institutions that presented only one or two interactions were removed to facilitate visualization.

\subsection{Survey of higher education institutions}

First, the scope of the research was defined to identify undergraduate and graduate (latosensu and stricto-sensu) institutions working on the themes of ES and ecologic economy. The survey covered the Brazilian public education institutions, as the organized information was only available on the website of the Brazilian Ministry of Education, which provides data on these institutions.

The identification of the institutions was carried out using the online search system of the e-Mec website (http://emec.mec.gov.br/). The selected options for search were: a) active higher education institutions; b) all Brazilian states; and c) public federal, state or municipal administration. The result was an automatically generated spreadsheet containing the name and address of each institution meeting the conditions. A total of 317 institutions were identified.

The information obtained was used for a new search, this time on the websites of each institution to identify science areas related to ES. The selected areas were: Geography, Ecology, Biology, Environmental Engineering, Environmental Management, Forestry Engineering, 
Agricultural Engineering, Civil Engineering and Agronomy. A search was then carried out to identify the undergraduate and graduate courses, their disciplines and the modules of these disciplines with the keywords: environmental services, ecosystem services, environmental economy and environmental value. Some complementary terms were considered, such as ecological economy, water resource economy, natural resource economy, forest economy, value of natural resources, economic value of the environment, and value of the environment. We collected information on the names of the module or discipline, their workload and the period of the course in which it was offered, the name of the course, its level and contact information.

Then, a form for the complementation of the missing data or the correction of the data on the site was sent by email to the contact of the courses and disciplines with the selected keywords in their programs. The email was sent on September 9, 2016 to 96 contacts and 33 responses were received. On April 13, 2017, the email was sent again to the contacts that had not responded to the previous one. The total forms answered reached 39. The geographical coordinates of the addresses of the institutions were used to display them on a map using ArcGIS10 from ESRI (http://www.esri.com/arcgis/about-arcgis).

\section{RESULTS AND DISCUSSION}

\subsection{The publication trends}

Two hundred and eighty-two publications were included in the database for the current study. The number of studies using the ES approach ranged from three in 2006 to fifty-nine in 2015 (Figure 1).
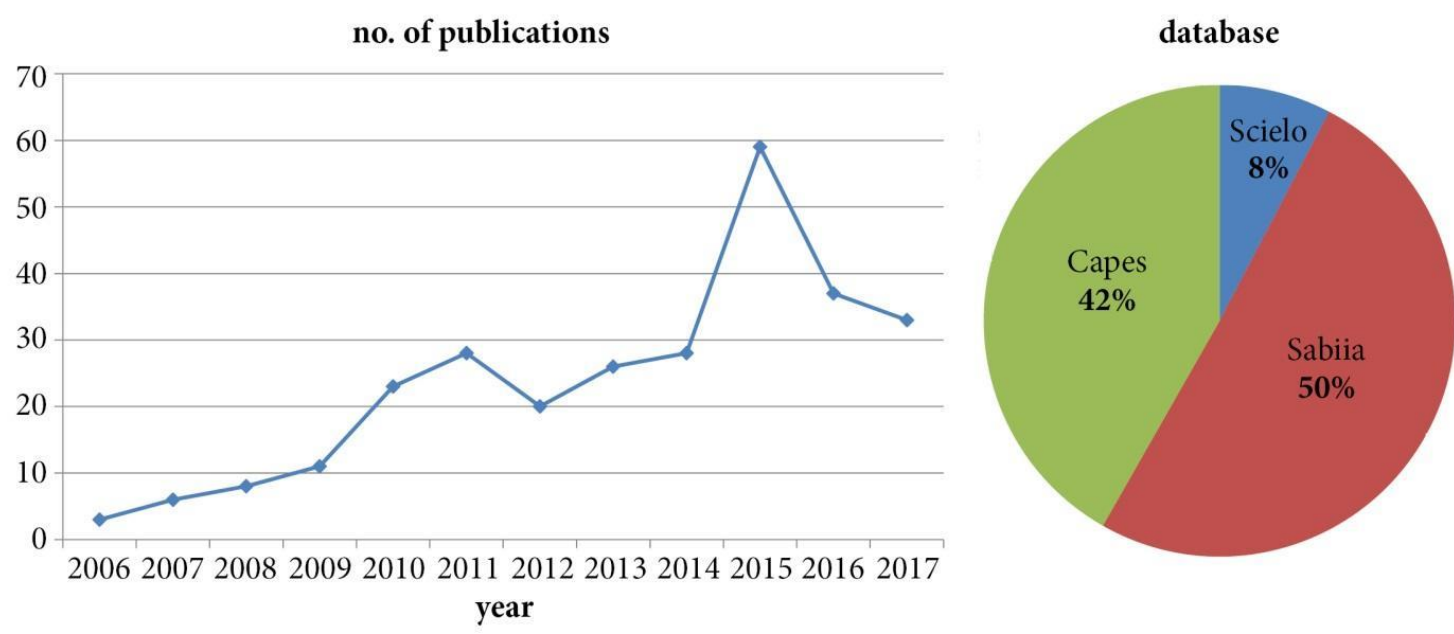

Figure 1. Number of publications according to year and biome.

The database covers six biomes. Most of the studies (37\%) do not focus on a specific biome. The most frequent biomes are the Atlantic Forest (31\%) and the Amazon (18\%) (Figure 1). As a form of publication, peer-reviewed articles represent $54 \%$, followed by book chapters $(21 \%)$ and articles in proceedings (14\%). The research focus is on analysis and opinion (19\%), assessment $(17 \%)$, economic valuation $(16 \%)$, review (14\%), methodological development (12\%), modeling (11\%), mapping (9\%) and monitoring (2\%) (Figure 2).

Regarding the classification of the Millennium Ecosystem Assessment our review found that most of the studies encompass all the ES or approach them in a general way (34\%). The most frequent ES is regulation (30\%), followed by provisioning (20\%), supporting (14\%), and cultural (2\%) (Figure 3). 


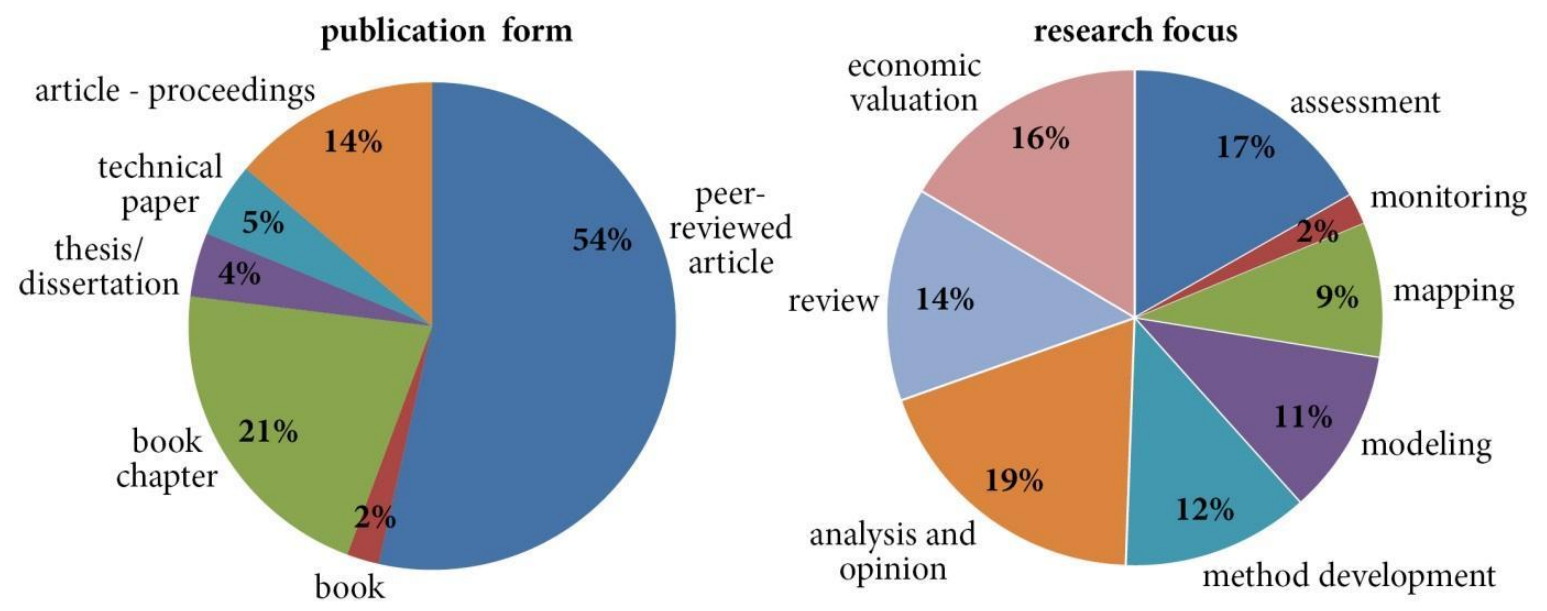

Figure 2. Percentage of publications by form and research focus.
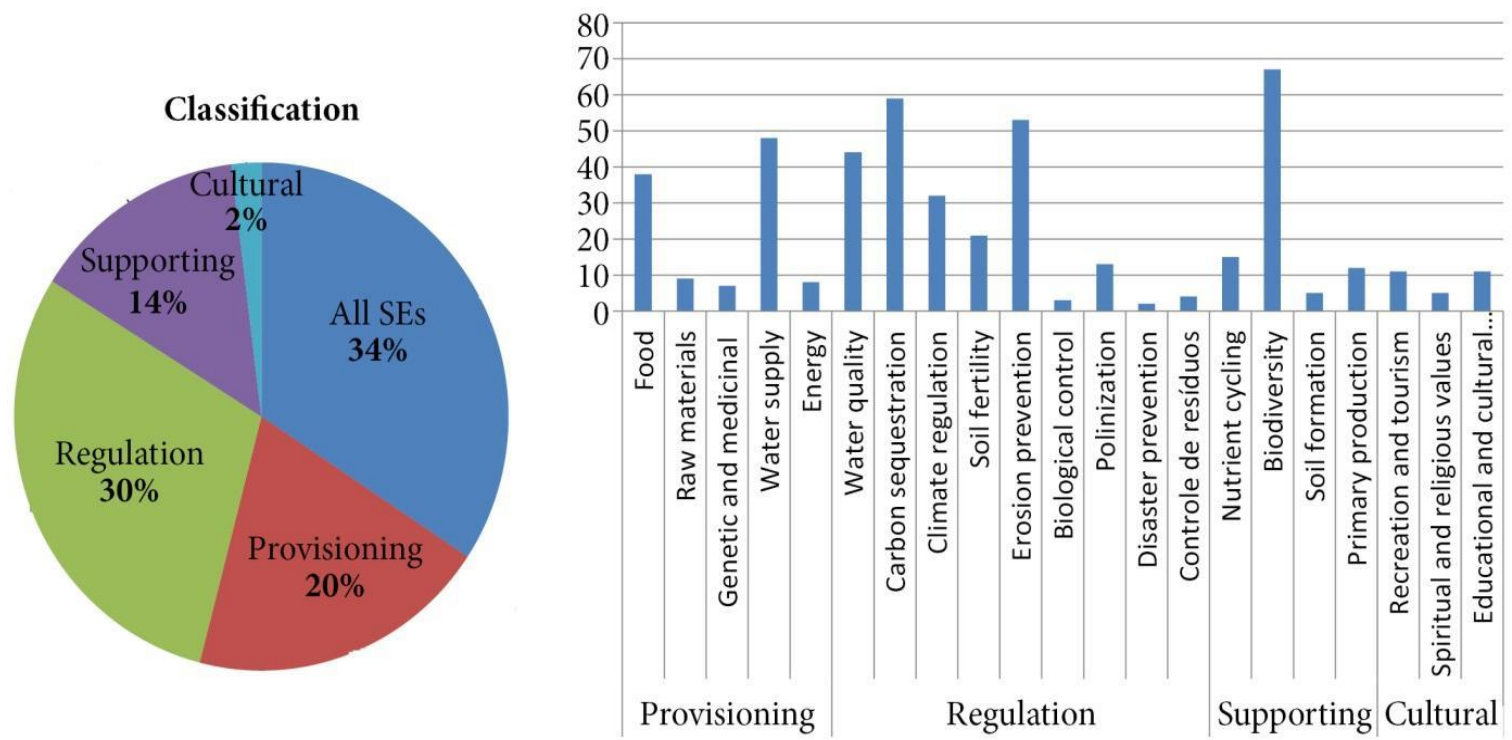

Figure 3. Percentage of publications and number of ecosystem services according to Millennium Ecosystem Assessment classification.

Among the ES, the most common are biodiversity (11.1\%), carbon sequestration $(9.8 \%)$, prevention and control of erosion $(8.8 \%)$, water supply $(8.0 \%)$, water quality $(7.3 \%)$ and food $(6.3 \%)$ (Figure 3$)$. Few publications $(\mathrm{n}=40)$ address a single service, 108 publications address 2 to $9 \mathrm{ES}$, while 134 publications address more than $10 \mathrm{ES}$ or approach ES in a general way. Studies reporting PES mechanisms represent $44 \%$ of the publications. The ES approach with technological development represents only $9 \%$ of the publications. In the network analysis of the relationships among institutions, it is possible to identify four main clusters based on the degree of interaction, differentiated by colors (Figure 4).

The size of the nodes indicates the connections among institutions, i.e., the larger the number of connections, the larger the node size. It is also possible to observe a higher number of interactions among Brazilian institutions and foreign institutions. At the same time, the clusters show a tendency of interactions among institutions from the same geographic region. It is also possible to observe that most of the institutions are from the South and Southeast regions of Brazil, demonstrating that the knowledge and the scientific relationships are concentrated in these regions. 'Abroad' refers to publications whose first authors are from institutions outside Brazil. 
The next section summarizes what we identified as the major ES studied to develop a current overview to drive future studies and research.

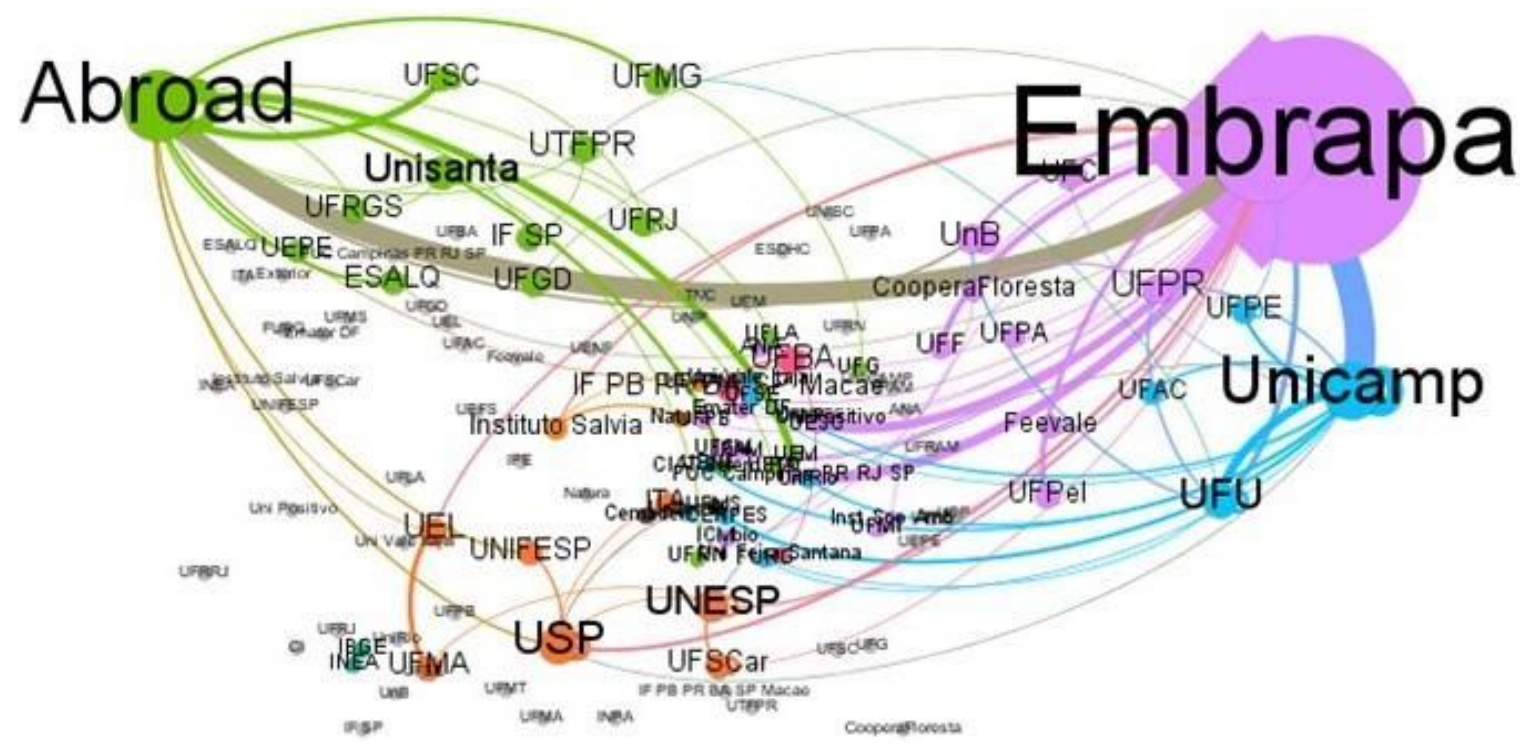

Figure 4. Network analysis of the relationships among publications.

\subsection{Provisioning services}

\subsubsection{Food}

Studies involving multiple ES generally include food production, which emphasizes the role of Brazil as an important producer of food, fiber and biofuels while holding mega biodiversity. Studies maintain that ES exist in productive systems only when natural ecosystems are able to keep them functioning, especially when they contain the source of genes that can help agricultural varieties become adapted to new climate conditions. To do so, it is essential to reduce the degradation of ES and promote the sustainable use of land and energy (Farley et al., 2015; Martinelli and Filoso, 2009). Other studies also incorporate the concept of provision services for land use and management and show positive impacts on ecosystems and human well-being (Barrett et al., 2013; Rosa and Sanchez, 2016). The approach from the economic point of view shows that the underpriced agricultural commodities lead to high environmental costs in the form of ES losses, largely borne by tropical countries, i.e., tropical nations subsidize the consumption of importing nations (Chang et al., 2016). The ability of Brazilian farmers to generate ES in land uses will be enhanced by public policies, which increase their capacity to respond promptly to changes in production technology and market opportunities (technical assistance with new products and production technologies, agricultural credit, and quick access to information on relative prices) (Börner et al., 2007).

\subsubsection{Water supply}

Land use, land-cover change scenarios, and hydrological models show problems related to water storage, food production and ES regulation, such as sediment control, water purification and retention (Koschke et al., 2014; Lima et al., 2014; Saad et al., 2016). The studies show the impacts of ecosystem degradation on water resources and propose forest restoration to protect them and increase aquifer recharge, groundwater flows and river discharge equilibrium (Watanabe and Ortega, 2011; Young and Bakker, 2014). Proposals such as Payments for Ecosystem Services (PES) and Reducing Emissions from Deforestation and Forest Degradation (REDD), focus on compensation for local communities in exchange for the preservation of natural forests and their ES (Klemick, 2011). 


\subsubsection{Timber and non-timber resources}

Studies that associate ES and raw materials, such as timber and non-timber resources, are scarce, and the few available use the economic valuation approach (Maciel et al., 2010; Fasiaben et al., 2015). Most of them are related to native forests and one study addresses trees in integrated production systems.

\subsection{Regulating services}

\subsubsection{Carbon sequestration}

The most common approach to carbon sequestration and carbon stocks is the mapping of multiple ES (Grimaldi et al., 2014; Koschke, 2015; LeClec'h et al., 2016), which includes an overview of several ES. More sophisticated models estimate the carbon flows or changes in carbon stocks as a result of changes in land use and land management (Watanabe and Ortega, 2014; 2011). Several studies also address the economic valuation of carbon (Mann et al., 2012; Song et al., 2014).

\subsubsection{Regulation of water quality}

Studies that associate regulating ES with water quality involve the maintenance and restoration of vegetation cover (Brancalion et al., 2014) and the valuation and charge for water use, from economic-ecologic modeling (Andrade et al., 2015; Garcia and Romeiro, 2015) and payment schemes for ecosystem services (PES) for water-resource protection (Young and Bakker, 2014; Zanella et al., 2014). Studies involving multiple ES generally include regulation of water quality, water supply and erosion prevention and control, which emphasize the development of a spatial approach for the effects of land use/land cover on the capacity to provide or maintain ES (Lima et al., 2017; Periotto and Tundisi, 2013).

\subsubsection{Erosion prevention and control}

Studies are focused on the quantification of several regulation ES as a land-use function (Ditt et al., 2010; Ferraz et al., 2014; Grimaldi et al., 2014; LeClec'h et al., 2016; Mathé and Rey-Valette, 2015). They also involve estimates of soil loss (Tôsto and Pereira, 2015), sediment input into water resources (Chaves, 2010) and the definition of conservation areas (Duarte et al., 2016).

\subsubsection{Maintenance of soil fertility}

Studies are generally associated with ES of erosion prevention and control and encompass estimated soil nutrient loss using the Universal Soil Loss Equation model (USLE) (Tôsto and Pereira, 2015). Soil fertility is also used as an indicator to assess forest degradation (Celentano et al., 2017). Few studies associate ES and production systems (Grimaldi et al., 2014; Ditt et al., 2010).

\subsubsection{Pollination}

Rrocesses that support pollination and their importance for human well-being and for agricultural productivity are well documented (Imperatriz-Fonseca and Nunes-Silva, 2010). The association with land use (Ferraz et al., 2014), richness of pollinators (LeClec'h et al., 2016), habitat connectivity (Giannini et al., 2015) and crop production (Mangabeira et al., 2015) are the most common approaches.

\subsection{Supporting services}

\subsubsection{Biodiversity maintenance}

The association between ecosystem functions and biodiversity is often used to assess and identify the consequences of human activities on the environment. Several ecosystem functions

\section{IPABH}

Rev. Ambient. Água vol. 14 n. 3, e2263 - Taubaté 2019 
are provided by soil fauna biodiversity (Marichal et al., 2014; Nichols et al., 2008). There are several studies that apply modeling and mapping to estimate the suitability of species habitat and the influence of the agricultural expansion in the maintenance of these habitats in order to analyze the distribution of species and its association with soil characteristics, climatic variables, topography and land use and cover (Brockerhoff et al., 2013; Kennedy et al., 2016; Leadley et al., 2014).

\subsubsection{Primary production (carbon)}

Primary production refers to the production of organic matter and increase in the vegetal biomass. Studies that evaluate primary production quantify ES as a function of land use (LeClec'h et al., 2016).

\subsection{Cultural services}

Cultural Services are services related to the aesthetic, spiritual, educational and recreational benefits offered by ecosystems. The research found few studies that evaluated people's perception of ES and the relationship they have with their environment (Mathé and Rey-Valette, 2015; Oliveira and Berkes, 2014) and with ecological restoration projects (Brancalion et al., 2014). The studies apply qualitative (Pereira and Campos, 2009; Ribeiro and Ribeiro, 2016; Souza Filho et al., 2014) and quantitative evaluations (Mariano et al., 2015; Rares and Brandimarte, 2014) and economic valuation of ES (Mathé and Rey-Valette, 2015), to point out that aesthetic values and opportunities for recreation and tourism are the most commonly perceived ES.

\subsection{Payment for ecosystem services programs (PES)}

Based on the framework of the Millennium Ecosystem Assessment (2005), the first studies in ES in Brazil carried out with the payments for nature services approach addressed the relationship between people and their environment, and water, carbon and biodiversity conservation. These studies evaluated environmental policies and programs (legal reserve, Proambiente, Bolsa Floresta, mechanized patrols) used as a mechanism to encourage conservation practices and these studies proposed models to predict the effects of policy changes on land use (e.g. Börner et al., 2007; Hall, 2008; Pereira, 2010). In addition, the studies focused on the assessment of how rural producers could receive payment for ES provided to the society to compensate for economic losses caused by the maintenance of ES (Begossi et al., 2011; Lima et al., 2014). Recently, studies have focused on the evaluation of adopted and successful PES mechanisms, which compensate landowners who agree to conserve natural forest areas associated with watershed protection (Lima et al., 2017). These studies combine payment schemes with the opportunity cost of land (Alarcon et al., 2016; 2017), indexes of quality and quantity of conservation and the relationships between the minimum amount of money that farmers would demand to get involved in PES programs for forest conservation and restoration (Young and Bakker, 2014; Zanella et al., 2014). The impacts of such programs on economic (regarding opportunity costs) and non-economic factors (such as trust and participation in scheme design) play a crucial role in determining decisions by land users on whether to participate in PES schemes in a sustained way (Zanella et al., 2014). The most successful programs are the hydrological. The project Conservador das Águas was created, with the support of ANA (Brazilian National Water Agency), stimulating PES. The project assists farmers that adopt soil conservation practices, apply rural sewage systems, and restore riparian zones, steep slopes and hilltops lands (Rosa et al., 2014; 2016; Gjorup et $a l ., 2016)$. Watershed models like the AgES simulate stream flow at the outlet of the basin, and can be used for evaluating the particular hydrological responses (Cruz et al., 2017). Articles also analyze the limitations of the approach which reconciles conservation and development,

Rev. Ambient. Água vol. 14 n. 3, e2263 - Taubaté 2019 
using insights from transaction costs economics and PES, providing alternatives and novel theoretical approaches to the conceptualization and analysis of these programs (Muradian 2013; Gómez-Baggethun and Muradian, 2015; Muradian and Gómez-Baggethun, 2013).

\subsection{Economic valuation}

The valuation of ES uses economic-ecological modeling as a tool to understand the ecological dynamics involved in it and the incorporation of the values of ES that would otherwise not be considered, such as water regulation services (Andrade and Romeiro, 2013). Several studies use valuation as an estimate of the economic dimension of natural resources to guide a decision-making process involving the use of natural capital 'assets', along with financial instruments and institutional arrangements (Andrade et al., 2015, 2012; Fasiaben et al., 2015; Klemick, 2011; Tôsto and Pereira, 2015). Estimates generated from different sets of data, models and techniques allow for the comparison of ES values against the income obtained by agricultural commodities (Mann et al., 2012). Other studies develop scenarios and simulation analyses based on geoprocessing, land use, climate and soil property models (e.g. InVest, MIMES). The models are generally comprised of biophysical and environmental assessment components, which convert input data into ES and economic benefits (Andrade et al., 2015; Garcia and Romeiro, 2015; Saad et al., 2016; Song et al., 2014).

\subsection{Technological development in ecosystem services}

Here we present an approach on issues related to the use of technologies applied to ES. Technological processes, development and application of models with the potential for use in other ES studies were considered technologies (e.g. Britto et al., 2012; Cruz et al., 2017; Duarte et al., 2016; Koschke et al., 2014; Lima et al., 2017). We found that most of the processes that could be considered technological were studies that applied some modeling tool associated with economic valuation. The systematic review pointed out that ES research in Brazil is more associated with the evaluation of natural resources and the analysis of their indicators and that there is a gap of technological packages for ES. This result shows that the research in ES in Brazil is still linked to scientific production, without advances in the direction of innovation and technological process.

\subsection{Ecosystem services in brazilian education institutions}

In the survey, 51 public institutions were identified. Altogether they have offered 93 disciplines which included in their program content the themes of environmental/ ecosystem services or economy/environmental value. The location of the institutions is shown in Figure 5.

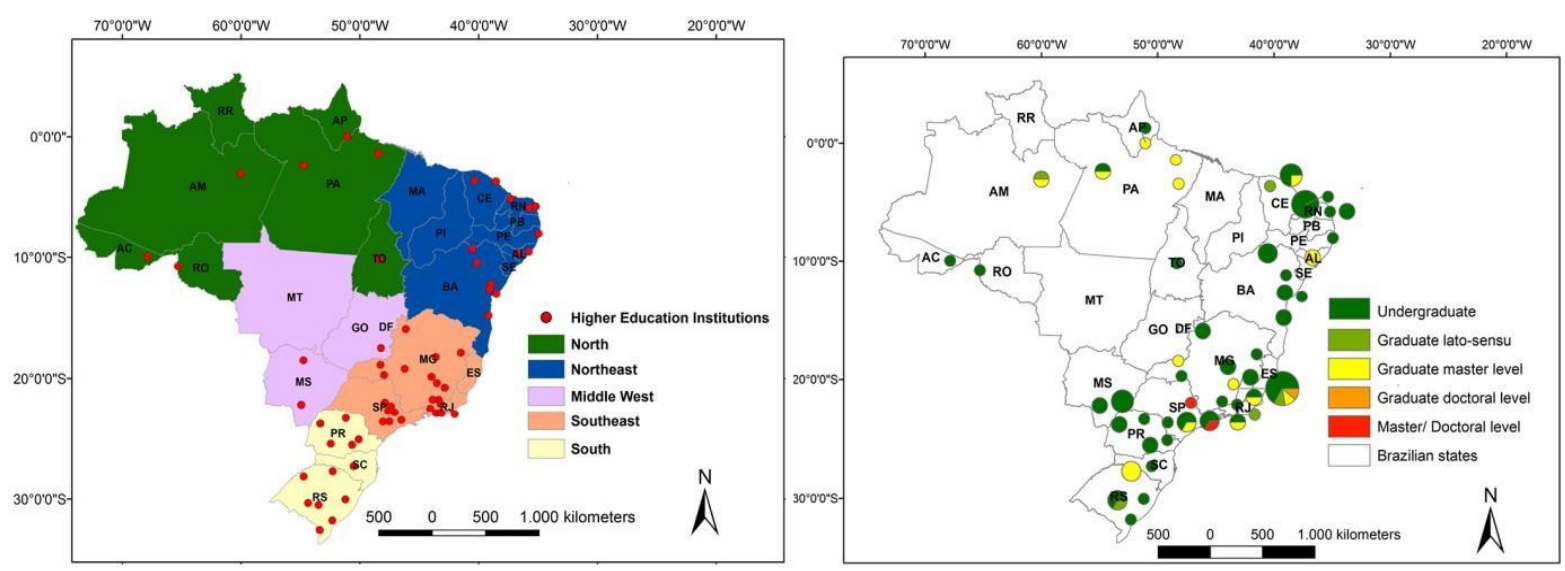

Figure 5. a) Brazilian higher education institutions that work on themes of ecosystem services and ecological economy; b) geographical distribution of the disciplines and the course level. 
The distribution of the institutions in the regions of Brazil was: seventeen in the Southeast, fourteen in the Northeast, nine in the South, eight in the North, and three in the Middle West. The number of disciplines offered in each region followed the same sequence: the Southeast with 34, the Northeast with 27, the South with 15, the North with 10 and the Middle West with 7.

The data collected in the form filled-out by the institutions allowed us to verify the periodicity of the disciplines: ten annual, fifteen semiannual and nine with undetermined periodicity out of a total of 34 responses to this item. The average workload of the disciplines was 55.82 hours, the maximum was 80 hours and the minimum was 30 hours for a total of 29 responses.

The Federal University of Viçosa (UFV) showed nine disciplines related to the themes, which were taught in six undergraduate and three graduate courses. It was the institution with the largest number of disciplines, followed by the Federal Rural Semiarid University (UFERSA) with six disciplines offered at undergraduate level. Most of the undergraduate courses with disciplines in the selected themes were Environmental Management (14 subjects), Environmental Engineering (13), Biological Sciences (12) and Forest Engineering (11).

The results indicated that the great majority of the disciplines in environmental services or ecology economy were offered at the undergraduate level. Minas Gerais state had the greatest number of disciplines, and it was the only one with disciplines in the selected themes for all levels. It was also observed that only the states of Minas Gerais and São Paulo had disciplines at the doctoral level (Figure 5).

\section{CONCLUSIONS}

The study of ES has grown quickly in the last two decades, and Brazil followed this evolution with an increase in the number of publications and expansion of disciplines in undergraduate and graduate courses. Although Brazil is a large and environmentally diversified country, our results showed that this theme in educational institutions is still concentrated in the Southeastern region, which means that the research activity follows some socioeconomic characteristics. The Brazilian SE is the most populated region and most economically developed. Additionally, the Atlantic Forest, which appeared as the most-studied biome, is mainly located in this region. However, despite these characteristics, there are still several environmental problems that threat the biodiversity and natural resources in this area. The Amazon is the second most-studied biome and is the largest forested area in Brazil. It is also the most famous Brazilian biome, which attracts world interest for the richness of its biodiversity. That can be an advantage regarding research partnerships and financial resources to study this biome; but, on the other hand, some studies may support groups with specific interests. Most of the studies were related to the evaluation of different types of ES and to the development of methodologies for their evaluation and monitoring. The most common ES are related to biodiversity, carbon sequestration and water. This was expected due to the major problems related to ES such as the loss of biodiversity and the jeopardizing of its functions in ecosystems; the global concern about climate change and the efforts to mitigate its effects; and, lastly, the growing concern about the frequent water-related problems in various parts of the world. Although the other types of ES were less frequent, it is important to highlight the broad scope of the themes, showing the studies are not limited to the great themes. Most of the studies $(33 \%)$ are analyses, opinion and revision, which is an indication that the SE theme is in full debate by the scientific community, probably because it is recent, and therefore reviews and analyses of work in this area must be consolidated so that consensus may be reached. Although these biomes are greatly important for the ES studies, the proportion of studies in Cerrado and Caatinga are much lower than the relative area they occupy in Brazil, indicating an imbalance.

Rev. Ambient. Água vol. 14 n. 3, e2263 - Taubaté 2019 
There was also a small contribution to cultural services. Studies involving economic approaches tend to increase, since the PES tool, mainly hydrological PES, has become a support for public policies. The results presented here point to some gaps and trends in ES research that may guide surveys and scenario analyses for future studies in different biomes and regions of the country.

\section{FUNDING}

This research was supported by the Embrapa project 'Environmental services in the Brazilian rural landscape: construction and sharing of knowledge' (grant number 05.14.11.001.00.00).

\section{REFERENCES}

ALARCON, G. G.; FREITAS, L. A. S.; FOUNTOURA, G. O.; MACEDO, C. X.; RIBEIRO, D. C. The challenges of implementing a legal framework for Payment for Ecosystem Services in Santa Catarina, Brazil. Natureza \& Conservação, v. 14, p. 132-136, 2016. https://dx.doi.org/10.1016/j.ncon.2016.05.003

ALARCON, G. G.; FANTINI, A. C.; SALVADOR, C. H.; FARLEY, J. Additionality is in detail: Farmers' choices regarding payment for ecosystem services programs in the Atlantic forest, Brazil. Journal of Rural Studies, v. 54, p. 177-186, 2017. https://dx.doi.org/10.1016/j.jrurstud.2017.06.008

ANDRADE, D. C.; ROMEIRO, A. R.; FASIABEN, M. C. R.; GARCIA, J. R. Dinâmica do uso do solo e valoração de serviços ecossistêmicos: notas de orientação para políticas ambientais. Desenvolvimento e Meio Ambiente, v. 25, p. 53-71, 2012. http://dx.doi.org/10.5380/dma.v25i0.26056

ANDRADE, D. C.; ROMEIRO, A. R. Valoração de serviços ecossistêmicos: por que e como avançar? Sustentabilidade em Debate, v. 4, p. 43-58, 2013.

ANDRADE, D. C.; TÔSTO, S. G.; SOBRINHO, R. P.; ROMEIRO, A. R. Avaliação do serviço ecossistêmico de regulação de água - aplicação do modelo Multi-scale Integrated Models of Ecosystem Services (Mimes) 1. In: TÔSTO, S. G.; BELARMINO, L. C.; ROMEIRO, A. R.; RODRIGUES, C. A. G. (Eds.). Valoração de serviços ecossistêmicos: metodologias e estudo de casos. Brasília, DF: Embrapa Territorial, 2015. p. 155-169.

BARRETT, K.; VALENTIM, J.; TURNER II, B. L. Ecosystem services from converted land: the importance of tree cover in Amazonian pastures. Urban Ecosystem, v. 16, p. 573591, 2013. https://dx.doi.org/10.1007/s11252-012-0280-1

BEGOSSI, A.; MAY, P. H.; LOPES, P. F.; OLIVEIRA, L. E. C.; VINHA, V.; SILVANO, R. A. M. Compensation for environmental services from artisanal fisheries in SE Brazil: Policy and technical strategies. Ecological Economics, v. 71, p.25-32, 2011. https://dx.doi.org/10.1016/j.ecolecon.2011.09.008

BÖRNER, J.; MENDOZA, A.; VOSTI, S. A. Ecosystem services, agriculture, and rural poverty in the Eastern Brazilian Amazon: Interrelationships and policy prescriptions. Ecological Economics, v. 64, p. 356-373, 2007. https://dx.doi.org/10.1016/j.ecolecon.2007.03.001

BRANCALION, P. H. S.; CARDOZO, I. V.; CAMATTA, A.; ARONSON, J.; RODRIGUES, R. R. Cultural ecosystem services and popular perceptions of the benefits of an ecological restoration project in the Brazilian Atlantic Forest. Restoration Ecology, v. 22, p.65-71, 2014. https://dx.doi.org/10.1111/rec.12025 
BRITTO, G. C.; KATO, O. R.; HERRERA, J. A. A prestação de serviços ambientais pode ser uma alternativa aos sistemas tradicionais da agricultura familiar no município de Pacajá, Amazônia Paraense - Brasil? Sustentabilidade em Debate, v. 3, p. 159-176, 2012.

BROCKERHOFF, E. G.; JACTEL, H.; PARROTTA, J. A.; FERRAZ, S. F. B. Management role of eucalypt and other planted forests in biodiversity conservation and the provision of biodiversity-related ecosystem services. Forest Ecology and Management, v. 301, p.43-50, 2013. https://doi.org/10.1016/j.foreco.2012.09.018

CELENTANO, D.; ROUSSEAU, G. X.; ENGEL, V. L.; ZELARAYÁN, M.; OLIVEIRA, E. C.; ARAUJO, A. C. M.; MOURA, E. G. Degradation of riparian forest affects soil properties and ecosystem services provision in eastern Amazon of Brazil. Land $\begin{array}{llllll}\text { Degradation } \& \text { Development, } & \text { v. 493, p.482-493, }\end{array}$ https://dx.doi.org/10.1002/ldr.2547

CHANG, J.; SYMES, W. S.; LIM, F.; CARRASCO, L. R. International trade causes large net economic losses in tropical countries via the destruction of ecosystem services. Ambio, v. 45, p.387-397, 2016. https://dx.doi.org/10.1007/s13280-016-0768-7

CHAVES, H. M. L. Relações de aporte de sedimento e implicações de sua utilização no pagamento por serviço ambiental em bacias hidrográficas. Revista Brasileira de Ciência do Solo, v. 34, p.1469-1477, 2010. https://dx.doi.org/10.1590/S0100-06832010000400043

COSTANZA, R.; HOWARTH, R. B.; KUBISZEWSKI, I.; LIU, S.; MA, C.; PLUMECOCQ, G.; STERN, D. I. Influential publications in ecological economics revisited. Ecological Economics, v. 123, p.68-76, 2016. https://dx.doi.org/10.1016/j.ecolecon.2016.01.007

CRUZ, P. P. N.; GREEN, T. R.; FIGUEIREDO, R. O.; PEREIRA, A. S.; KIPKA, H.; SAAD, S. I.; SILVA, J. M.; GOMES, M. A. F. Hydrological modeling of the Ribeirão das Posses - An assessment based on the Agricultural Ecosystem Services (AgES) watershed model. Revista Ambiente \& Água, v. 12, p. 351-364, 2017. https://dx.doi.org/10.4136/1980-993X

DE GROOT, R. S.; WILSON, M. A.; BOUMANS, R. MJ. A typology for the classification, description and valuation of ecosystem functions, goods and services. Ecological economics, v. 41, p. 393-408, 2002. https://doi.org/10.1016/S0921-8009(02)00089-7

DITT, E. H.; MOURATO, S.; GHAZOUL, J.; KNIGHT, J. Forest conversion and provision of ecosystem services in the Brazilian Atlantic Forest. Land Degradation \& Development, v. 603, p. 591-603, 2010. https://doi.org/10.1002/ldr.1010

DUARTE, G. T.; RIBEIRO, M. C.; PAGLIA, A. P. Ecosystem services modeling as a tool for defining priority areas for conservation. Plos One, v. 11, p. 1-19, 2016. https://dx.doi.org/10.1371/journal.pone.0154573

EGOH, B. N.; O'FARRELL, P. J.; CHAREF, A.; JOSEPHINE GURNEY, L.; KOELLNER, T.; NIBAM ABI, H.; EGOH, M.; WILLEMEN, L. An African account of ecosystem service provision: use, threats and policy options for sustainable livelihoods. Ecosystem Services, v. 2, p. 71-81, 2012. https://dx.doi.org/10.1016/j.ecoser.2012.09.004

FARLEY, J.; SCHMITT, A.; BURKE, M.; FARR, M. Extending market allocation to ecosystem services: moral and practical implications on a full and unequal planet. $\begin{array}{llllll}\text { Ecological Economics, } & \text { v. 117, p. 244-252, }\end{array}$ https://dx.doi.org/10.1016/j.ecolecon.2014.06.021 
FASIABEN, M. C. R.; ROMEIRO, A. R.; PERES, F. C.; MAIA, A. G. Impacto econômico da reserva legal sobre diferentes tipos de unidades de produção agropecuária. In: TÔSTO, S. G.; BELARMINO, L. C.; ROMEIRO, A. R.; RODRIGUES, C. A. G. (Eds.). Valoração de serviços ecossistêmicos: metodologias e estudo de casos. Brasília, DF: Embrapa Territorial, 2015. p. 279-313.

FERRAZ, S. F. B.; FERRAZ, K. M. P. M. B.; CASSIANO, C. C.; BRANCALION, P. H. S.; LUZ, D. T. A.; AZEVEDO, T. N.;TAMBOSI, L. R.; METZGER, J. P. How good are tropical forest patches for ecosystem services provisioning? Landscape Ecology, v. 29, p. 187-200, 2014. https://dx.doi.org/10.1007/s10980-014-9988-z

GARCIA, J. R.; ROMEIRO, A. R. Valoração e Cobrança pelo Uso da água: uma abordagem econômico-ecológica. In: TÔSTO, S. G.; BELARMINO, L. C.; ROMEIRO, A. R.; RODRIGUES, C. A. G. (Eds.). Valoração de serviços ecossistêmicos: metodologias e estudo de casos. Brasília, DF: Embrapa Territorial, 2015. p. 73-93.

GIANNINI, T. C.; TAMBOSI, L. R.; ACOSTA, A. L.; JAFFÉ, R. Safeguarding ecosystem services: a methodological framework to buffer the joint effect of habitat configuration and climate change. Plos One, v. 19, p. 1-19, 2015. https://dx.doi.org/10.1371/journal.pone.0129225

GJORUP, A. F.; FIDAlGO, E. C. C.; PRADO, R. B.; SCHUlER, A. E. Análise de procedimentos para seleção de áreas prioritárias em programas de pagamento por serviços ambientais hídricos. Revista Ambiente \& Água, v. 11, p. 225-238, 2016. https://dx.doi.org/10.4136/ambi-agua.1782

GÓMEZ-BAGGETHUN, E.; MURADIAN, R. In markets we trust? Setting the boundaries of market-based Instruments in ecosystem services governance. Ecological Economics, v. 117, p. 217-224, 2015. https://dx.doi.org/10.1016/j.ecolecon.2015.03.016

GRIMALDI, M.; OSZWALD, J.; DOLÉDEC, S.; HURTADO, M.; MIRANDA, I.; SARTRE, X. A.; ASSIS, W. S.; CASTAÑEDA, E.; DESJARDINS, T.; DUBS, F.; GUEVARA, E.; GOND, V.; LIMA, T. T. S.; MARICHAL, R.; FERNANDO, M.; MITJA, D.; NORONHA, N.C.; OLIVEIRA, M.N.D.; RAMIREZ, B.; RODRIGUEZ, G.; SARRAZIN, M.; JUNIOR, M. L. S.; COSTA, L. G. S.; SOUZA, S. L.; VEIGA, I.; VELASQUEZ, E.; LAVELLE, P. Ecosystem services of regulation and support in Amazonian pioneer fronts : searching for landscape drivers. Landscape Ecology, v. 29, p. 311-328, 2014. https://dx.doi.org/10.1007/s10980-013-9981-y

HALL, A. Better RED than dead: paying the people for environmental services in Amazonia. Philosophical Transactions of the Royal Society B: Biological Sciences, v. 363, p. 1925-1932, 2008. https://dx.doi.org/10.1098/rstb.2007.0034

IMPERATRIZ-FONSECA, V. L.; NUNES-SILVA, P. As abelhas, os serviços ecossistêmicos e o Código Florestal Brasileiro. Biota Neotropica, v. 10, p. 59-62, 2010. https://dx.doi.org/10.1590/S1676-06032010000400008

JIANG, W. Ecosystem services research in China: A critical review. Ecosystem services, v. 26, p.10-16, 2017. https://dx.doi.org/10.1016/j.ecoser.2017.05.012 
KENNEDY, C. M.; HAWTHORNE, P. L.; MITEVA, D. A.; BAUMGARTEN, L.; SOCHI, K.; MATSUMOTO, M.; EVANS, J. S.; POLASKY, S.; HAMEL, P.; VIEIRA, E. M.; FERREIRA, P.; SEKERCIOGLU, C. H.; DAVIDSON, A. D.; UHLHORN, E. M.; KIESECKER, J. Optimizing land use decision-making to sustain Brazilian agricultural profits, biodiversity and ecosystem services. Biological Conservation, v. 204, p. 221230, 2016. https://dx.doi.org/10.1016/j.biocon.2016.10.039

KLEMICK, H. Shifting cultivation, forest fallow, and externalities in ecosystem services: Evidence from the Eastern Amazon. Journal of Environmental Economics and Management, v. 61, p. 95-106, 2011. https://dx.doi.org/10.1016/j.jeem.2010.07.003

KOSCHKE, L.; LORZ, C.; FÜRST, C.; LEHMANN, T.; MAKESCHIN, F. Assessing hydrological and provisioning ecosystem services in a case study in Western Central Brazil. Ecological Process, v. 3, p. 2-15, 2014. https://doi.org/10.1186/2192-1709-3-2

KOSCHKE, L. The multi-criteria assessment of ecosystem services at a landscape level to support decision-making in regional and landscape planning. 2015. 45p. Dissertation (Doctor) - Technische Universitat Dresden, Tharandt, 2015.

KUMAR, P. (Ed.). TEEB The economics of ecosystems and biodiversity ecological and economic foundations. London; Washington: Earthscan, 2010.

LEADLEY, P.; PROENÇA, V.; FERNÁNDEZ-MANJARRÉS， J.; PEREIRA， H.M.; ALKEMADE, R.; BIGGS, R.; BRULEY, E.; CHEUNG, W.; COOPER, D.; FIGUEIREDO, J.; GILMAN, E.; GUÉNETTE, S.; HURTT, G.; MBOW, C.; OBERDORFF, T.; REVENGA, C.; SCHARLEMANN, J. P. W.; SCHOLES, R.; SMITH, M. S.; SUMAILA, U. R.; WALPOLE, M. Interacting regional-scale regime shifts for biodiversity and ecosystem services. BioScience, v. 64, p. 665-679, 2014. https://dx.doi.org/10.1093/biosci/biu093

LECLEC'H, S.; OSZWALD, J.; DECAENS, T.; DESJARDINS, T.; DUFOUR, S.; GRIMALDI, M.; JEGOU, N.; LAVELLE, P. Mapping multiple ecosystem services indicator: Toward an objective-oriented approach. Ecological Indicators, v. 69, p. 508521, 2016. https://dx.doi.org/10.1016/j.ecolind.2016.05.021

LIMA, J. E. F. W.; AQUINO, F.G.; CHAVES, T.A.; LORZ, C. Development of a spatially explicit approach for mapping ecosystem services in the Brazilian Savanna - MapES. $\begin{array}{llllll}\text { Ecological Indicators, } & \text { v. } & \text { 82, } & \text { p. }\end{array}$ https://dx.doi.org/10.1016/j.ecolind.2017.07.028

LIMA, L. S.; COE, M. T.; SOARES FILHO, B. S.; CUADRA, S. V.; DIAS, L. C. P.; COSTA, M. H.; LIMA, L. S.; RODRIGUES, H. O. Feedbacks between deforestation, climate, and hydrology in the Southwestern Amazon: Implications for the provision of ecosystem $\begin{array}{llllll}\text { services. Landscape Ecology, v. 29, p. 261-274, } 2014 . & \end{array}$ https://dx.doi.org/10.1007/s10980-013-9962-1

MACIEL, R. C. G.; REYDON, B. P.; COSTA, J. A.; SALES, G. O. Pagando pelos serviços ambientais: uma proposta para a Reserva Extrativista Chico Mendes. Acta Amazonica, v. 40, p. 489-498, 2010.

MANGABEIRA, J. A. C.; TÔSTO, S. G.; ROMEIRO, A. R.; GREGO, C. R. Análise espacial aplicada à valoração de serviços ecossistêmicos da agricultura: exemplo do café em Machadinho d'Oeste, RO. In: TÔSTO, S. G.; BELARMINO, L. C.; ROMEIRO, A. R.; RODRIGUES, C. A. G. (Eds.). Valoração de serviços ecossistêmicos: metodologias e estudo de casos. Brasília, DF: Embrapa Territorial, 2015. p. 55-71. 
MANN, M. L.; KAUFMANN, R. K.; MARIE, D.; GOPAL, S.; BALDWIN, J. G.; DEL, M. Ecosystem service value and agricultural conversion in the Amazon: implications for policy intervention. Environmental \& Resource Economics, v. 53, p.279-295, 2012. https://dx.doi.org/10.1007/s10640-012-9562-6

MARIANO, M. V.; AGOSTINHO, C. M. V. B. DE A.; BONILlA, S. H.; AGOSTINHO, F.; GIANNETTI, B. F. Avaliação em emergia como ferramenta de gestão nos parques urbanos de São Paulo. Gestão \& Produção, v. 22, p. 443-458, 2015. https://dx.doi.org/10.1590/0104-530X712-13

MARICHAL, R.; GRIMALDI, M.; M, A.F.; OSZWALD, J.; PRAXEDES, C.; HERNAN, D.; COBO, R.; HURTADO, P.; DESJARDINS, T.; LOPES, M.; GONZAGA, L.; SOUZA, I.; NASCIMENTO, M.; OLIVEIRA, D.; BROWN, G.G.; TSÉLOUIKO, S.; BONIFACIO, M.; DECAËNS, T.; VELASQUEZ, E.; LAVELLE, P. Soil macroinvertebrate communities and ecosystem services in deforested landscapes of Amazonia. Applied Soil Ecology, v. 83, p. 177-185, 2014. https://dx.doi.org/10.1016/j.apsoil.2014.05.006

MARTINELLI, L. A.; FILOSO, S. Balance between food production, biodiversity and ecosystem services in Brazil: a challenge and an opportunity. Biota Neotropica, v. 9, p. 21-25, 2009. https://dx.doi.org/10.1590/S1676-06032009000400001

MARTÍNEZ-HARMS, M. J.; BALVANERA, P. Methods for mapping ecosystem service supply: a review. International Journal of Biodiversidy Science, Ecosystem, Services $\begin{array}{lllllll}\text { \& } & \text { Management, } & \text { v. } & 8, & \text { p. } & 17-25, & \end{array}$ https://dx.doi.org/10.1080/21513732.2012.663792

MATHÉ, S.; REY-VALETTE, H. Local knowledge of pond fish-farming ecosystem services: management implications of stakeholders' perceptions in three different contexts (Brazil, France and Indonesia). Sustainability, v. 7, p. 7644-7666, 2015. https://dx.doi.org/10.3390/su7067644

MILLENNIUM ECOSYSTEM ASSESSMENT. Ecosystems and human well-being: synthesis. Washington, DC: Island Press: 2005.

MURADIAN, R. Payments for ecosystem services as incentives for collective action. Society $\begin{array}{lllll}\text { \& Natural } & \text { Resources, } & \text { v. 26, }\end{array}$ https://dx.doi.org/10.1080/08941920.2013.820816

MURADIAN, R.; GÓMEZ-BAGGETHUN, E. The institutional dimension of "market-based instruments" for governing ecosystem services: introduction to the special issue. Society $\begin{array}{llllll}\text { \& Natural Resources, } & \text { v. 26, p. 1113-1121, }\end{array}$ https://dx.doi.org/10.1080/08941920.2013.829380

NICHOLS, E.; SPECTOR, S.; LOUZADA, J.; LARSEN, T.; AMEZQUITA, S.; FAVILA, M.E. Ecological functions and ecosystem services provided by Scarabaeinae dung beetles. Biological Conservation, v. 141, p. 1461-1474, 2008. https://dx.doi.org/10.1016/j.biocon.2008.04.011

OLIVEIRA, L. E. C.; BERKES, F. What value São Pedro's procession? Ecosystem services from local people's perceptions. Ecological Economics, v. 107, p. 114-121, 2014. https://dx.doi.org/10.1016/j.ecolecon.2014.08.008

PEREIRA, S. N. C. Payment for environmental services in the amazon forest: how can conservation and development be reconciled? Journal of Environmental Development, v. 19, p. 171-190, 2010. https://dx.doi.org/10.1177/1070496510368047

Rev. Ambient. Água vol. 14 n. 3, e2263 - Taubaté 2019 
PEREIRA, M. A.; CAMPOS, W. G. de. Pagamento por serviços ambientais aliando conservação e ecoturismo. Revista Brasileira do Ecoturismo, v. 2, p. 255-272, 2009.

PERIOTTO, N. A; TUNDISI, J. G. Ecosystem services of UHE Carlos Botelho (Lobo/Broa): a new approach for management and planning of dams multiple-uses. Brazilian Journal of Biology, v. 73, p. 471-482, 2013. https://dx.doi.org/10.1590/S151969842013000300003

PLANT, R.; RYAN, P. Ecosystem services as a practicable concept for natural resource management: some lessons from Australia. The International Journal of Biodiversity Science, Ecosystems Services \& Management, v. 9, p. 44-53, 2013. https://dx.doi.org/10.1080/21513732.2012.737372

PRADO, R. B.; FIDALGO, E. C. C.; FERREIRA, J. N.; CAMPANHA, M. M.; PARRON, L. M. V.; MATTOS, L. M.; PEDREIRA, B. C. C. G.; MONTEIRO, J. M. G; TURETTA, A. P. D.; MARTINS, A. L. S.; DONAGEMMA, G. K.; COUTINHO, H. L. C. Pesquisas em serviços ecossistêmicos e ambientais na paisagem rural do Brasil. Revista Brasileira de Geografia Física, v. 8, p. 610-622, 2015.

RARES, C. DE S.; BRANDIMARTE, A. L. O desafio da conservação de ambientes aquáticos e manutenção de serviços ambientais em áreas verdes urbanas: o caso do Parque Estadual da Cantareira. Ambiente \& Sociedade, v. 17, p. 111-128, 2014.

RIBEIRO, F. P.; RIBEIRO, K. T. Participative mapping of cultural ecosystem services in Pedra Branca State Park, Brazil. Natureza \& Conservação, v. 14, p. 120-127, 2016. https://doi.org/10.1016/j.ncon.2016.09.004

ROSA, F. S.; TONELLO, K. C.; VALENTE, R. O. A.; LOURENCO, R. W. Estrutura da paisagem, relevo e hidrografia de uma microbacia como suporte a um programa de pagamento por serviços ambientais relacionados à água. Revista Ambiente \& Água, v. 9, p. 526-539, 2014. https://dx.doi.org/10.4136/ambi-agua.1326

ROSA, F. S.; TONELLO, K. C.; VALENTE, R. O. A.; LOURENCO, R. W. Selection of priority areas for payment of environmental services: an analysis at the watershed level. Revista Ambiente \& Água, v. 11, p. 448-461, 2016. https://dx.doi.org/10.4136/ambiagua. 1809

ROSA, J. C. S.; SANCHEZ, L. E. Advances and challenges of incorporating ecosystem services into impact assessment. Journal of Environmental Management, v. 180, p. 485-492, 2016. https://dx.doi.org/10.1016/j.jenvman.2016.05.079

SAAD, S. I.; ROCHA, H. R.; SILVA, J. M. The impact of roads and sediment basins on simulated river discharge and sediment flux in an experimental catchment designed to improve ecosystem services. Hydrology and Earth System Sciences Discussions, p. 150, 2016. https://dx.doi.org/10.5194/hess-2015-490

SEPPELT, R.; FATH, B.; BURKHARD, B.; FISHER, J. L.; GRÊT-REGAMEY, A.; LAUTENBACH, S.; PERT, P.; HOTES, S.; SPANGENBERG, J.; VERBURG, P. H.; VAN OUDENHOVEN, A. P. E. Form follows function? Proposing a blueprint for ecosystem service assessments based on reviews and case studies. Ecological Indicators, v. 21, p. 145-154, 2012. https://dx.doi.org/10.1016/j.ecolind.2011.09.003

Rev. Ambient. Água vol. 14 n. 3, e2263 - Taubaté 2019 
SONG, X. P.; HUANG, C.; TOWNSHEND, J. R. An integrated framework for evaluating the effects of deforestation on ecosystem services. IOP Conference Series: Earth and Environmental Science, v. 17, p. 1-6, 2014. https://dx.doi.org/10.1088/1755$1315 / 17 / 1 / 012061$

SOUZA FILHO, J. R.; SANTOS, R. C.; SILVA, I. R.; ELLIFF, C. I. Evaluation of recreational quality, carrying capacity and ecosystem services supplied by sandy beaches of the municipality of Camaçari, northern coast of Bahia, Brazil. Journal of Coastal Research, v. 70, p. 527-532, 2014. https://dx.doi.org/10.2112/SI70-089.1

TÔSTO, S. G.; PEREIRA, L. C. A valoração ambiental da erosão do solo na cana-de-açúcar em São Paulo. In: TÔSTO, S. G.; BELARMINO, L. C.; ROMEIRO, A. R.; RODRIGUES, C. A. G. (Eds.). Valoração de serviços ecossistêmicos: metodologias e estudo de casos. Brasília, DF: Embrapa Territorial, 2015. p. 343-355.

WATANABE, M. D. B.; ORTEGA, E. Ecosystem services and biogeochemical cycles on a global scale: valuation of water, carbon and nitrogen processes. Environmental Sciences \& Policy, v. 14, p. 594-604, 2011. https://dx.doi.org/10.1016/j.envsci.2011.05.013

WATANABE, M. D. B.; ORTEGA, E. Dynamic emergy accounting of water and carbon ecosystem services: A model to simulate the impacts of land-use change. Ecological $\begin{array}{lllll}\text { Modelling, } & \text { v. } & 271, & \text { p. } & 113-131,\end{array}$ https://dx.doi.org/10.1016/j.ecolmodel.2013.03.006

YOUNG, C. E. F.; BAKKER, L. B. Payments for ecosystem services from watershed protection: a methodological assessment of the Oasis Project in Brazil. Natureza \& Conservação, v. 12, p.71-78, 2014. https://dx.doi.org/10.4322/natcon.2014.013

ZANELLA, M. A.; SCHLEYER, C.; SPEELMAN, S. Why do farmers join Payments for Ecosystem Services (PES) schemes? An Assessment of PES water scheme participation in Brazil. Ecological Economics, v. 105, p.166-176, 2014. 